\title{
PABPC1 Gene
}

National Cancer Institute

\section{Source}

National Cancer Institute. PABPC1 Gene. NCI Thesaurus. Code C143072.

This gene is involved in binding to poly(A)RNA. 